\title{
Green extraction of polyphenolic-polysaccharide conjugates from Pseuderanthemum palatiferum (Nees) Radlk.: Chemical profile and anticoagulant activity
}

Ho, Truc Cong; Kiddane, Anley Teferra; Sivagnanam, Saravana Periaswamy; Park, Jin-Seok; Cho, YeonJin; Getachew, Adane Tilahun; Nguyen, Thanh-Tuyen Thi; Kim, Gun-Do; Chun, Byung-Soo

Published in:

International Journal of Biological Macromolecules

Link to article, DOI:

10.1016/j.ijbiomac.2020.04.113

Publication date:

2020

Document Version

Peer reviewed version

Link back to DTU Orbit

Citation (APA):

Ho, T. C., Kiddane, A. T., Sivagnanam, S. P., Park, J-S., Cho, Y-J., Getachew, A. T., Nguyen, T-T. T., Kim, GD., \& Chun, B-S. (2020). Green extraction of polyphenolic-polysaccharide conjugates from Pseuderanthemum palatiferum (Nees) Radlk.: Chemical profile and anticoagulant activity. International Journal of Biological Macromolecules, 157, 484-493. https://doi.org/10.1016/j.ijbiomac.2020.04.113

\section{General rights}

Copyright and moral rights for the publications made accessible in the public portal are retained by the authors and/or other copyright owners and it is a condition of accessing publications that users recognise and abide by the legal requirements associated with these rights.

- Users may download and print one copy of any publication from the public portal for the purpose of private study or research.

- You may not further distribute the material or use it for any profit-making activity or commercial gain

- You may freely distribute the URL identifying the publication in the public portal 


\section{Journal Pre-proof}

Green extraction of polyphenolic-polysaccharide conjugates from Pseuderanthemum palatiferum (Nees) Radlk.: Chemical profile and anticoagulant activity

Truc Cong Ho, Anley Teferra Kiddane, Saravana Periaswamy Sivagnanam, Jin-Seok Park, Yeon-Jin Cho, Adane Tilahun Getachew, Thanh-Tuyen Thi Nguyen, Gun-Do Kim, Byung-Soo

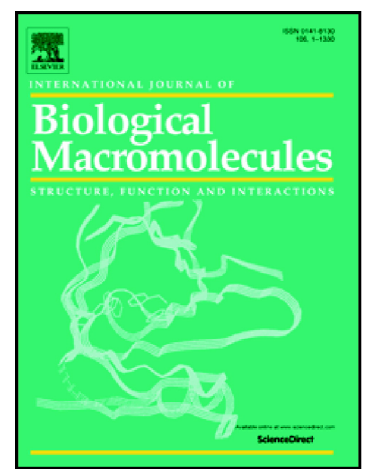

Chun

PII:

S0141-8130(20)32975-5

DOI: https://doi.org/10.1016/j.ijbiomac.2020.04.113

Reference: BIOMAC 15322

To appear in: $\quad$ International Journal of Biological Macromolecules

Received date: 22 January 2020

Revised date: $\quad 2$ April 2020

Accepted date: $\quad 16$ April 2020

Please cite this article as: T.C. Ho, A.T. Kiddane, S.P. Sivagnanam, et al., Green extraction of polyphenolic-polysaccharide conjugates from Pseuderanthemum palatiferum (Nees) Radlk.: Chemical profile and anticoagulant activity, International Journal of Biological Macromolecules (2020), https://doi.org/10.1016/j.ijbiomac.2020.04.113

This is a PDF file of an article that has undergone enhancements after acceptance, such as the addition of a cover page and metadata, and formatting for readability, but it is not yet the definitive version of record. This version will undergo additional copyediting, typesetting and review before it is published in its final form, but we are providing this version to give early visibility of the article. Please note that, during the production process, errors may be discovered which could affect the content, and all legal disclaimers that apply to the journal pertain.

(C) 2020 Published by Elsevier. 


\title{
Green extraction of polyphenolic-polysaccharide conjugates from Pseuderanthemum palatiferum (Nees) Radlk.: chemical profile and anticoagulant activity
}

Truc Cong Ho a , Anley Teferra Kiddane ${ }^{\mathrm{b}}$, Saravana Periaswamy Sivagnanam ${ }^{\mathrm{c}}$, Jin-Seok Park ${ }^{\mathrm{a}}$, Yeon-Jin Cho a , Adane Tilahun Getachew ${ }^{\mathrm{d}}$, Thanh-Tuyen Thi Nguyen ${ }^{\mathrm{e}}$, Gun-Do Kim ${ }^{\mathrm{b}}$, Byung-Soo Chun ${ }^{\mathrm{a} *}$

${ }^{a}$ Department of Food Science and Technology, Pukyong National University, Busan 48513, Republic of Korea

${ }^{\mathrm{b}}$ Department of Microbiology, Pukyong National University, Busan 48513, Republic of Korea

${ }^{\mathrm{c}}$ Department of Food Chemistry \& Technology, Teagasc Food Research Centre, Ashtown, Dublin 15, Ireland

${ }^{\mathrm{d}}$ National Food Institute, Technical University of Denmark, 2800 Kgs. Lyngby, Denmark

${ }^{\mathrm{e}}$ Vinh Long City Health Center, Vinh Long province, Vietnam

\author{
*Corresponding author \\ Professor Byung-Soo Chun
}

Department of Food Science and Technology, Pukyong National University

599-1 Daeyeon-3dong, Nam-Gu, Busan, Korea 608-737

Tel: +82-51-629-5830, Fax: +82-51-629-5824

Email: bschun@pknu.ac.kr 


\begin{abstract}
In this study, pressurized liquid extraction (PLE) of polyphenolic-polysaccharide (PP) from Pseuderanthemum palatiferum (Nees) Radlk. leaves was carried out and compared with a conventional technique using $0.1 \mathrm{M}$ sodium hydroxide. The extracts were purified according to the method reported previously to obtain PP conjugates which were further studied about chemical profiles and anticoagulant activity. Fourier-transform infrared spectroscopy (FTIR), UV-Vis, nuclear magnetic resonance (NMR), gel permeation chromatography (GPC), and spectrophotometry analysis were used to characterize the selected PP conjugates. The results showed that PP conjugates comprised of carbohydrate, phenolic, and protein constituents with the yield ranged from $2.76 \%$ to $14.34 \%$. Seven mono sugars containing in all conjugates were determined using high-performance liquid chromatography (HPLC), namely, arabinose, fucose, galactose, glucose, mannose, rhamnose, and xylose. PP conjugates obtained from PLE at $150{ }^{\circ} \mathrm{C}$ (PP-PLE5) exhibited better anticoagulant activity than those found at $200{ }^{\circ} \mathrm{C}$ and comparable to that of the conventional technique. On gel permeation chromatography, PP-PLE5 showed a broad molecular mass from 6 to $642 \mathrm{kDa}$. From the obtained results, PLE can be used as a green effective technique for the recovery of PP conjugate from $P$. palatiferum leaves.
\end{abstract}

\title{
Keywords
}

Pressurized liquid extraction

Polyphenolic-polysaccharide conjugates

Anticoagulant activity 


\section{Introduction}

Recently, polyphenolic-polysaccharide (PP) conjugates obtained from medicinal plants exhibited high biological activities, such as anticoagulant and platelet aggregation inhibitory activities [1-6]. Plant samples were isolated and purified through several stages using different organic solvents [3] to obtain PP conjugates. However, it has been reported that conventional extraction techniques require long extraction time, high energy consumption, and more organic solvents, of which the latter may not only cause negative effects on human health upon ingestion due to their residue in the final products but also be costly to purchase and dispose of [7-12]. In recent years, modern techniques have been commonly used for the extraction of nutraceuticals from foods and herbal plants. These techniques retain huge advantages, such as less toxic solvents, safe operation, ease of scale-up, short time, and low energy consumption compared with conventional methods. Therefore, the influences of "green" extraction techniques on the structures and biological activities of the PP conjugate from medicinal plants should be considered [13].

Among modern extraction methods, subcritical water extraction (SWE) or pressurized liquid extraction (PLE), which mainly uses water as an available resource and environmentally benign solvent, has exhibited the potential to replace conventional techniques [14]. SWE drives at temperatures above the boiling point of water $\left(100{ }^{\circ} \mathrm{C}-374{ }^{\circ} \mathrm{C}\right)$ and at a pressure high enough to keep it in the liquid state (1-22 MPa). Under these thermodynamic conditions, the solubility of organic compounds in water increases with a small increase in temperature. The water properties affecting the solubility of organic solutes in water, controlled by fine-tuning water temperature, are polarity or dielectric constant, and water density [15]. The solubility of organic compounds in water increases significantly in the subcritical water state [16]. Thus, water has been used to 
extract bioactive compounds from a variety of natural resources [17-20]. Besides, the use of solvent mixtures is also found to improve the extraction efficiency by enhancing the solubility and increasing the interaction between the solvent and targeted compounds. For instance, in a mixture of two solvents, one could enhance the soluble capacity, whereas the other would improve the desorption of the compound [8]. A mixture of water and ethanol has been used as a "green" solvent in PLE to extract bioactive compounds from grape marc [21], phenolic compounds and sugars from flower resources [19], and polyphenols from goldenberry [22]. In addition to solvent selection, extraction temperature is one of the most important factors which has a significant influence on the efficiency and selectivity in PLE. Elevated temperatures can reduce surface tension and viscosity of the solvent, resulting in the enhancement of the solvent penetration inside the matrix, thus causing the compounds to be dissolved faster by the solvent. The solvent flow rate is also a considerable factor that may affect the extraction efficiency of bioactive compounds from the sample [23].

P. palatiferum is a new medicinal plant that was first found in Vietnam in the late twentieth century. Thereafter, various bioactive compounds from the leaf of this plant, including phytosterols (stigmasterol and $\beta$-sitosterol), flavonoids (kaempferol 3-methyl ether 7-O- $\beta$ glucoside and apigenin 7-O- $\beta$-glucoside), saponins, and lipids [24], were determined. In recent studies, the crude extracts from the leaf exhibited various biological activities, such as anticancer [25] and antidiabetic activities [26], hypoglycemic [27] and hypertensive effect [28], antilipolytic and alpha-amylase inhibitory [29], anti-inflammatory [30], acetylcholinesterase inhibitory effect [31], and antimicrobial [17, 32] activities. Consequently, this plant is recommended in folk medicine in some Southeast Asian countries for promoting people's health and treating various diseases, including hypertension, diarrhea, arthritis, hemorrhoids, 
stomachache, tumors, colitis, bleeding [27]. Owing to its significant biological activities and containing bioactive components, $P$. palatiferum could be a potential source of PP.

Although there are many reports about the use of PLE, studies about the recovery of polyphenolic-polysaccharide (PP) conjugate using PLE are scarce. Given the advantages of this green technique, there is a considerable gap in recovering PP conjugates from herbal plants. Therefore, in this study, PLE was used to isolate PP from $P$. palatiferum leaves and then extracts were purified to achieve PP conjugates. The obtained PP conjugates were compared with that of the conventional method using $0.1 \mathrm{M} \mathrm{NaOH}$ in terms of their anticoagulant activity and chemical profiles. Finally, the selected conjugates were characterized using advanced characterization techniques.

\section{Materials and methods}

\subsection{Materials and chemicals}

P. palatiferum leaves were collected in Western Highlands, Vietnam, in October 2017 and provided by Thanh Binh Co., Ltd (Ho Chi Minh, Vietnam). Dried leaves containing 9.96\% \pm $0.03 \%(\mathrm{w} / \mathrm{w})$ of moisture and $15.5 \%$ of ash were ground with a particle size $\leq 710 \mathrm{~nm}$ and stored at $-60{ }^{\circ} \mathrm{C} \pm 1{ }^{\circ} \mathrm{C}$ for further use. The aPTT and PT reagents, including pooled human blood plasma from healthy donors, were purchased from Thermo Fisher Scientific, Pittsburgh, PA. Standard chemicals, including Trolox (6-hydroxy-2,5,7,8-tetramethylchroman-2-carboxylic acid), DPPH (2,2-diphenyl-1-picrylhydrazyl), $\mathrm{ABTS}^{+}$[2,2-azinobis-(3-ethylbenzothiazoline-6-sulfonic acid)], gallic acid, heparin, arabinose, fucose, galactose, glucose, mannose, xylose, and rhamnose, were all purchased from Sigma-Aldrich Chemical Co., USA. Other solvents and chemicals used in this study were of analytical grade.

\subsection{Extraction of PP from $P$. palatiferum leaves}


Pressurized liquid extraction (PLE) of PP from $P$. palatiferum leaves was performed using the semicontinuous system (Figure 1). In this study, two extraction solvents were water and $60 \%$ aqueous ethanol, extraction temperatures were $150{ }^{\circ} \mathrm{C}$ and $200{ }^{\circ} \mathrm{C}$, and flow rates of 5 and $10 \mathrm{~mL}$ $\min ^{-1}$ were employed. The extracts were filtered under vacuum and evaporated to dryness.

The conventional technique using $0.1 \mathrm{M} \mathrm{NaOH}$ was performed according to the method described in the previous study [3] with some modifications. Briefly, the sample was extracted by $250 \mathrm{~mL}$ of $0.1 \mathrm{M} \mathrm{NaOH}$ at room temperature for $24 \mathrm{~h}$, and then for $6 \mathrm{~h}$ at boiling point, under the reflux. Afterward, the mixture was centrifuged at $4000 \mathrm{rpm}$ for $15 \mathrm{~min}$ to obtain the supernatant. Then, the supernatant was neutralized with $1 \mathrm{M} \mathrm{HCl}$ and evaporated to dryness. The sample $(6 \mathrm{~g})$ was used for all experiments.

\subsubsection{Purification of PP from P. palatiferum extracts}

The dryness parts obtained from PLE and $0.1 \mathrm{M} \mathrm{NaOH}$ techniques were further purified according to the method described in the previous study [3] with some modifications. Briefly, the dryness parts were dissolved in $250 \mathrm{~mL}$ of deionized water and extracted twice with $\mathrm{n}$-hexane (water/hexane $-1: 1 \mathrm{v} / \mathrm{v}$ ) for $6 \mathrm{~h}$ at $69{ }^{\circ} \mathrm{C}$. This step was followed by the extraction of the water part twice with diethyl ether at $34{ }^{\circ} \mathrm{C}$ for $6 \mathrm{~h}$. The separated water parts were evaporated into a paste-like form. Then, the paste-like forms were treated with methanol (2 L) at room temperature, filtered in a glass funnel under reduced pressure, and dried at room temperature. Finally, the residues were dissolved in distilled water, intensively dialyzed against distilled water (4 L) for 5 days, and then freeze-dried to give dark isolates. The final PP conjugates obtained from different extraction methods were named PP-PLE1 (PP obtained from PLE at $5 \mathrm{~mL} / \mathrm{min}-200{ }^{\circ} \mathrm{C}-60 \%$ ethanol), PP-PLE2 (PP obtained from PLE at $5 \mathrm{~mL} / \mathrm{min}-200{ }^{\circ} \mathrm{C}$-water), PP-PLE3 (PP obtained from PLE at $5 \mathrm{~mL} / \mathrm{min}-150{ }^{\circ} \mathrm{C}$-water), PP-PLE4 (PP obtained from PLE at $10 \mathrm{~mL} / \mathrm{min}-150{ }^{\circ} \mathrm{C}-$ 
$60 \%$ ethanol), PP-PLE5 (PP obtained from PLE at $10 \mathrm{~mL} / \mathrm{min}-150{ }^{\circ} \mathrm{C}$-water), PP-PLE6 (PP obtained from PLE at $10 \mathrm{~mL} / \mathrm{min}-200{ }^{\circ} \mathrm{C}-60 \%$ ethanol), PP-NaOH (PP obtained from conventional technique using $0.1 \mathrm{M} \mathrm{NaOH})$.

\subsection{Chemical characterization}

The total carbohydrate content was measured by the phenol sulfuric acid method [33]; glucose was used as a standard and expressed as weight percentage (wt $\%$ ). The determination of total phenolic and flavonoid contents was performed using the previous methods $[34,35]$, gallic acid and rutin were used as standard compounds. The total protein content was estimated according to the Pomory assay [36], and bovine serum albumin (BSA) was used as a reference. The content of uronic acids (UA) was established using the 96-well plate carbazole reaction assay [37] and Dglucuronic acid was used as a reference compound. The free radical scavenging activity of selected PP conjugates was also determined according to the method described in the previous study [38]. All the assays were measured using a multimode reader (BioTek Instruments, Inc., USA).

\subsection{High-performance liquid chromatography (HPLC) of monosaccharides}

For hydrolysis steps, sample (3 mg) was mixed with $72 \%$ of $\mathrm{H}_{2} \mathrm{SO}_{4}(30 \mu \mathrm{L})$ and incubated at $30{ }^{\circ} \mathrm{C}$ for $1 \mathrm{~h}$ before being diluted with $840 \mu \mathrm{L}$ of deionized water. The mixture was then treated at $121^{\circ} \mathrm{C}$ for $30 \mathrm{~min}$ using an autoclave. The resulting mixture was neutralized by $42 \mathrm{mg}$ of $\mathrm{CaCO}_{3}$ and centrifuged to achieve the supernatant.

In 1-phenyl-3-methyl-5-pyrazolone (PMP) derivatization procedure [39], the supernatant (100 $\mu \mathrm{L})$ was sequentially mixed with $0.6 \mathrm{M} \mathrm{NaOH}(100 \mu \mathrm{L})$ and $0.5 \mathrm{M}$ PMP in methanol $(200 \mu \mathrm{L})$ and thoroughly vortexed before incubating at $70{ }^{\circ} \mathrm{C}$ in an oven for $1.5 \mathrm{~h}$. After being cooled down to room temperature, the mixture was neutralized with $0.3 \mathrm{M} \mathrm{HCl}(200 \mu \mathrm{L})$ and vigorously 
vortexed. To the resulting mixture, chloroform $(1 \mathrm{~mL})$ was added and carefully shaken. The chloroform layer was discarded and this step was repeated five times. Finally, the aqueous layer was filtered using a $0.45 \mu \mathrm{m}$ filter for HPLC analysis. Both hydrolyzed samples and standards were treated under the same procedure. HPLC analysis was done according to the method reported previously [39]. Briefly, a mixture of $0.1 \mathrm{M}$ phosphate buffer $(\mathrm{pH}$ 6.7) and acetonitrile (83:17, v/v) was used as a mobile phase. The PMP derivatives elution was performed with the mobile phase through the Eclipse Plus $\mathrm{C}_{18}$ column $(250 \times 4.6 \mathrm{~mm}$ i.d., $5 \mu \mathrm{m})$ with a flow rate of $1 \mathrm{~mL} / \mathrm{min}$. An injection volume of $20 \mu \mathrm{L}$ and $\mathrm{UV}$ absorbance at $245 \mathrm{~nm}$ were set for the analysis. Seven mono sugars were used for establishing standard curves with concentrations from 50 to $1000 \mu \mathrm{g} / \mathrm{mL}$.

\subsection{In vitro clotting assays}

The in vitro anticoagulant activity of PP conjugates from $P$. palatiferum leaves was investigated using two different conventional diagnostic assays - the aPTT and PT tests using the procedures described by Pawlaczyk [5]. The concentrations of analyzed samples in deionized water ranged from 3.91 to $4000 \mu \mathrm{g} \mathrm{mL}^{-1}$. The aPTT and PT tests were conducted in triplicate.

\subsection{Gel permeation chromatography (GPC) analysis}

The molecular weight of the selected PP was determined using gel permeation chromatography (GPC). Before the analysis, the sample was dissolved in deionized water $\left(3 \mathrm{mg} \mathrm{mL}^{-1}\right)$, filtered through a $0.45-\mu \mathrm{m}$ pore-size Nylon filter, and degassed. The injection volume was maintained at $100 \mu \mathrm{L}$, and $0.1 \mathrm{M}$ of $\mathrm{NaNO}_{3}$ was used as a developing solvent with a flow speed of $1 \mathrm{~mL} \mathrm{~min}^{-1}$. The molecular mass of polysaccharide and its distribution were analyzed at $40{ }^{\circ} \mathrm{C}$ using Tosoh EcoSEC HLC-8320 GPC equipped with RI detector and TSKgel guard PW $\times 1+2 \times$ TSKgel MPW $\times 1+$ TSKgel G2500PW $\times 1(7.8 \times 300 \mathrm{~mm})$ column. The determination of the molecular 
mass of the sample was based on the calibration curve of the pollutant standards $(6,1$ to $642 \times$ $10^{3} \mathrm{~g} \mathrm{~mol}^{-1}$ ). The results were analyzed using the EcoSEC software.

\subsection{Fourier transform infrared (FTIR) spectroscopy}

The spectra of $\mathrm{KBr}$ pellets, including $2 \mathrm{mg}$ of $\mathrm{PP}$ and $250 \mathrm{mg}$ of $\mathrm{KBr}$, were determined using Cary 640 Fourier transform infrared (FTIR) spectrometer (Agilent Technologies Inc., USA). The wavenumber region and the number of scans used in this study were 4000 to $400 \mathrm{~cm}^{-1}$ and 16 , respectively.

\subsection{Nuclear magnetic resonance (NMR) spectroscopy}

The nuclear magnetic resonance $\left({ }^{1} \mathrm{NMR}\right)$ and heteronuclear single quantum coherence (HSQC) NMR spectra of samples $(70 \mathrm{mg})$ were recorded in $\mathrm{D}_{2} \mathrm{O}(1 \mathrm{~mL})$ on FT-NMR $600 \mathrm{MHz}(\mathrm{JEOL}$ JNM-ECP600, Japan).

\subsection{Ultraviolet-visible (UV-Vis) analysis}

The UV spectra of the purified sample were measured in the wavelength range of 200-700 nm using a multi-microplate reader (Synergy HTX BioTek Instruments, Winooski, VT, USA) at $25{ }^{\circ} \mathrm{C}$.

\subsection{Statistical analysis}

Statistical analysis was conducted using Microsoft Office Excel 2010. The standard deviation of data was expressed as mean \pm S.D.

\section{Results and discussion}

\subsection{Isolation and chemical characterization of PP from P. palatiferum}

PP conjugates were successfully isolated from various medicinal plants and exhibited high anticoagulant activity [1-4, 40, 41]. The previous extraction procedure [42] was also modified to improve the anticoagulant activity on the selection of enzymes of coagulant cascade [2]. 
In this study, PP conjugates from P. palatiferum leaves were isolated using PLE and compared with conventional methods using $0.1 \mathrm{M} \mathrm{NaOH}$. According to the previous report, subcritical water at $150{ }^{\circ} \mathrm{C}$ and $200{ }^{\circ} \mathrm{C}$ and pressure of $5 \mathrm{MPa}$ has dielectric constants of approximately 44.12 and 34.90, respectively [43]. Consequently, water was not appropriate to remove nonpolar and less polar compounds, as compared with $60 \%$ aqueous ethanol under the same conditions or alkaline at ambient temperature and pressure. No color appeared in the upper phase (hexane or diethyl ether) of the mixture containing the extracts obtained from PLE using water (Fig. S1). This indicated that there were no nonpolar and less polar compounds extracted. Therefore, the use of hexane and diethyl ether can be ignored in the purification procedure employing subcritical water as an extraction solvent. On the other hand, the yellow color was observed in the upper phase of the remaining mixtures demonstrating the presence of some unexpected compounds.

However, the thermodynamic properties of water at $150{ }^{\circ} \mathrm{C}$ and $200{ }^{\circ} \mathrm{C}$ are close to that of methanol at ambient temperature and pressure [44]. Consequently, some waxes, isoprenoids, and even some low molecular mass polyphenolics can be extracted [2]. To eliminate these unwanted components, the dryness part needed to be treated with methanol. From this careful observation, we proposed a new procedure for the recovery and purification of PP conjugates from medicinal plants using PLE (Figure 2).

The PP conjugates attained from different isolation techniques showed different colors (Figure S2). Specifically, PP-PLE1, PP-PLE4, and PP-PLE6 possessed beige and brown color; PP-PLE3 was blonde; whereas PP-PLE5 and PP-NaOH had a dark brown color. Moreover, texture between the conjugates was also diverse, for instance, $\mathrm{PP}-\mathrm{NaOH}$ had a layer structure, whereas all PP conjugates achieved from the PLE technique had a soft fiber structure. The difference in 
extraction conditions might result in a reduction of the molecular weight of PP conjugates, leading to variations in their structures.

The yields of PP conjugates were also varied and depended on the extraction processes (Table 1). The technique using $0.1 \mathrm{M} \mathrm{NaOH}$ provided the highest yield (14.34\%) as compared with those of PLE. With the treatment at a mild temperature, the conventional technique might not render any thermal degradation of PP. On the other hand, PLE is usually carried out under an elevated temperature that could decompose more polysaccharides. This results in the formation of low molecular weight compounds, such as glucose and other saccharides [45], leading to a decrease in the final yield after dialysis. Regarding the type of extraction solvents in PLE, water extracted more PP than 60\% aqueous ethanol (PP-PLE1 and PP-PLE2 or PP-PLE3 and PP-PLE4). Also, a solvent flow rate of $10 \mathrm{~mL} \mathrm{~min}{ }^{-1}$ was more effective than that of $5 \mathrm{~mL} \mathrm{~min}^{-1}$ in improving extraction efficiency (PP-PLE1 and PP-PLE6 or PP-PLE3 and PP-PLE5, Table 1). In the dynamic extraction mode, the efficiency increased with the increase in the flow rate owing to the promotion of mass transfer of the solutes from the sample matrix [46]. According to a previous study, pressurized hot water extraction of black tea at a flow rate of $12 \mathrm{~mL} \mathrm{~min}^{-1}$ gave a higher yield than that found at $6 \mathrm{~mL} \min ^{-1}[23]$.

As shown in Table 1, PP-PLE1, PP-PLE2, and PP-PLE6 comprised higher carbohydrate and protein content than those found in PP-NaOH, PP-PLE3, PP-PLE4, and PP-PLE5. This can be explained by the low viscosity and surface tension of water at elevated temperatures, thus promoting better penetration of water into the matrix particles to improve the extraction [46]. Moreover, under these conditions, cellulose, a major component in the plant cell wall and consisting of glucose units, linked by $\beta$-(1-4)-glycosidic bonds, is rapidly hydrolyzed to its constituents [45]. In a previous study, the total sugar and protein contents extracted from defatted 
rice bran reached peaks at $200{ }^{\circ} \mathrm{C}$ and $240{ }^{\circ} \mathrm{C}$, respectively [47]. However, low contents of uronic acid, TPC, and TFC were found in the conjugates obtained at $200{ }^{\circ} \mathrm{C}$ (Table 1). This might have resulted from the thermal degradation of these components under severe temperature treatment. The highest content of TPC and TFC was observed in the PP-PLE5 conjugate (264.66 $\pm 2.54 \mathrm{mg} \mathrm{GAE} \mathrm{g}^{-1}$ and $135.83 \pm 1.66 \mathrm{mg} \mathrm{RE} \mathrm{g}^{-1}$, respectively). Besides, seven monosaccharides were determined using HPLC and presented in Table 1. Rhamnose, glucose, and galactose were dominant among the constituents of carbohydrates; whereas, fucose and xylose are the least. The formation of xylose depends upon the treating temperature during the extraction process. The high amount of xylose was observed with the application of temperature at $200{ }^{\circ} \mathrm{C}$.

\subsection{Anticoagulant activity}

The examination of the anticoagulant activity of PP conjugates from P. palatiferum leaves was done and presented in Tables 2 and 3. In these tests, the use of pooled human blood plasma from healthy donors was followed according to the manufacturer's instruction. Heparin sodium salt from porcine intestinal mucosa $\left(180 \mathrm{UI} \mathrm{mg}^{-1}\right)$ was used as a reference substance. The concentrations of PP conjugates in deionized water ranged from 3.91 to $4000 \mu \mathrm{g} \mathrm{mL} L^{-1}$.

For aPTT tests, PP-NaOH and PP-PLE5 conjugates at a concentration of $2000 \mu \mathrm{g} \mathrm{mL}^{-1}$ strongly inhibited plasma clot formation for more than $10 \mathrm{~min}$; whereas, the PP-PLE3 and PP-PLE4 conjugates required a higher concentration $\left(4000 \mu \mathrm{g} \mathrm{mL}^{-1}\right)$ to reach that duration. We found that at the concentration above $1000 \mu \mathrm{g} \mathrm{mL}^{-1}$, PP-NaOH conjugates extended the clotting time longer than those found in PP-PLE3, PP-PLE4, and PP-PLE5 conjugates. However, with concentrations no more than $500 \mu \mathrm{g} \mathrm{mL}^{-1}$, the converse trend was observed when PP-PLE3, PP-PLE4, and PPPLE5 conjugates showed better inhibition of plasma clot formation in the reacting mixture. This may be due to the carbohydrate contents in these conjugates were noticeable higher than that of 
PP-NaOH (Table 1). Although the degradation of PP might slightly occur during hydrothermal treatment, their biological activity remained. Consequently, the conjugates with dense PP more effectively inhibited Factor Xa.

PP-PLE1 was the least active even though it contained the most carbohydrates (Table 1). Owing to the influence of elevated temperature during the PLE extraction process, PP structure was strongly fragmented, leading to a decrease in anticoagulant activity. It is reported that polysaccharides with higher molecular weight exhibited greater anticoagulant capacity [43].

PT test is utilized to perceive bleeding disorders. The extension of the PT test often implies the insufficiency in one or more of the factors in the extrinsic or common pathway of blood coagulation. This insufficiency can result from hereditary coagulation disorders, vitamin $\mathrm{K}$ shortage, liver disease or drug administration. The use of the PT test is common to examine oral anticoagulant therapy because it is sensitive to insufficiency in Factors II, VII, and X1,2 and for general pre-operative screening. However, the PT test is not sensitive to insufficiency in the intrinsic coagulation system (i.e. Factors VIII, IX, XI, and VII) or to platelet dysfunctions [41]. PP-NaOH and PP-PLE5 were observed as the most active anticoagulant which prolonged the clotting time two and a half min at the concentration of $4000 \mu \mathrm{g} / \mathrm{mL}$ (Table 3). The inhibition of the coagulation process by the extrinsic pathway of the enzymatic cascade is usually associated with some side effects, for example, uncontrolled bleeding episodes [2].

\subsection{Antioxidant activities}

DPPH and ABTS radical scavenging assays of PP-PLE5, PP-NaOH conjugates, and Trolox were investigated and shown in Figure 3. In these assays, analyzed samples were dissolved in deionized water with concentrations from 15.6 to $250 \mu \mathrm{g} \mathrm{mL} L^{-1}$. Concentrations of Trolox in methanol were between 1.5 and $9.5 \mu \mathrm{g} \mathrm{mL} L^{-1}$. Sample and standard solutions were used to 
scavenge against $0.05 \mathrm{M} \mathrm{DPPH}$ and $0.05 \mathrm{M}$ ABTS solutions with the absorbance of approximately 1.4. The $\mathrm{IC}_{50}$ values of PP-PLE5 were 151.5 and $111.5 \mu \mathrm{g} \mathrm{mL}^{-1}$ for DPPH and ABTS, respectively. Those values of PP-NaOH were 237.7, and $152.1 \mu \mathrm{g} \mathrm{mL}^{-1}$, for DPPH and ABTS radicals, respectively. They were higher than that found in Trolox $\left(7.76\right.$ and $6.72 \mu \mathrm{g} \mathrm{mL}^{-1}$, for DPPH and ABTS radicals, respectively), indicating that the samples had lower antioxidant capacity than the standard compound. The differences in the antioxidant capacity of the two conjugates can be explained by their TPC and carbohydrate contents. These values of the PPPLE5 conjugate were noticeable greater than that of PP-NaOH (Table 1).

\subsection{FTIR, $U V-V i s$, and NMR analysis}

Fourier-transform infrared analysis (FTIR) spectra of PP-PLE5 and PP-NaOH conjugates were measured and presented in Figure 4A. In general, the spectra of the two samples indicated some similarities and differences from each other. In the frequency region of approximately $3420 \mathrm{~cm}^{-1}$, the two spectra displayed wide intensive bands, which are representative of the stretching vibrations $(\mathrm{O}-\mathrm{H})$ of hydroxyl groups of saccharides, as well as phenolic groups [3]. Two lowintensity bands were observed in both spectra at frequencies of $2933-2854 \mathrm{~cm}^{-1}$ and $2927-2852$ $\mathrm{cm}^{-1}$ derived from the stretching vibrations of $(\mathrm{C}-\mathrm{H})$. The first band is antisymmetric stretching vibrations of $\left(-\mathrm{CH}_{2}-\right)$, whereas the second one is characteristic of symmetric interactions of such bonds, both of them confirmed the presence of $\left(-\mathrm{CH}_{2}-\right)$ group which is typically for aromatic and aliphatic structures, respectively $[2,3]$. Similarly, symmetric stretching vibrations of $(C=O)$ bonds at a frequency of $1421 \mathrm{~cm}^{-1}$ observed in both spectra were also recognizable [3]. A band at the region of 1330 and $1340 \mathrm{~cm}^{-1}$, which confirmed the presence of phenyl $\mathrm{O}-\mathrm{H}$ structure, was also visible in both spectra [3]. Other intensive bands, which are characteristic of $\mathrm{C}=\mathrm{O}$ and $\mathrm{C}=\mathrm{C}$ bonds, at the same frequency region of $1639 \mathrm{~cm}^{-1}$ in both analyzed spectra, were detected [2]. 
Two bands at $1560-1542 \mathrm{~cm}^{-1}$ and $1560-1544 \mathrm{~cm}^{-1}$ related to phenolic fragments were observed in both spectra [3]. Other visible bands of the two spectra representative of the stretching vibrations $(\mathrm{C}-\mathrm{O}-\mathrm{C})$ were recognized at 1238 and $1251 \mathrm{~cm}^{-1}$ [3]. FTIR bands at the frequency region of 1143 and $1145 \mathrm{~cm}^{-1}$ are dominated by the glycosidic linkage $(\mathrm{C}-\mathrm{O}-\mathrm{C})$ contribution [48]. Bands at frequencies of $1051-1047 \mathrm{~cm}^{-1}$ were typically for the presence of mannose, arabinose, and rhamnose constituents [48]. The band shape is influenced by galactan from the side chain, which has a band at around $1072 \mathrm{~cm}^{-1}$; however, the band at 1095 could not be explained yet [48]. Bandsat lower frequencies of 887 and $896 \mathrm{~cm}^{-1}$ in both spectra confirmed the presence of $\beta$-anomer [48].

The UV-Vis spectrum of the isolates was reported in $250 \mu \mathrm{g} \mathrm{mL}^{-1}$ solutions at a wavelength range of 200-700 nm and was presented in Figure 4B. The peaks at the absorbance of $230 \mathrm{~nm}$ observed in both spectra indicated the presence of protein [49]. The maximum absorbance at 260 $\mathrm{nm}$ might be attained from the aromatic structures of phenolic origin $(\mathrm{C}=\mathrm{C}$ bonds of aromatic rings). Another wide band with low intensity at the absorbance of approximately $330 \mathrm{~nm}$ is typically for the presence of subunits of phenolic conjugates to each other (to the $\mathrm{C}=\mathrm{C}$ bonds of the aromatic structures) [1].

The ${ }^{1} \mathrm{H}$ NMR spectra of PP-PLE5 and PP-NaOH conjugates containing three visible regions of signals were presented in Figure 5A. First, in the region at $\delta 3.0-0.5 \mathrm{ppm}$, broad signals were mostly caused by the aliphatic fragments $\left(-\mathrm{CH}_{2}-\right)$ and $\left(-\mathrm{CH}_{3}\right)$ of phenolic compounds, protein content, and $-\mathrm{CH}_{3}$ of $\mathrm{C} 6$ of deoxyhexose (Rha). The powerful signals in the region at $\delta 5.5-3.3$ ppm typically constituted the carbohydrate part, and signals at $\delta 7.5-6.5 \mathrm{ppm}$ attained the aromatic segments of phenolic fragments [2]. Specifically, two signals in the region between 1.0 and $1.25 \mathrm{ppm}$ obtained from $-\mathrm{CH}_{3}$ protons of $\mathrm{O}-2$ and $\mathrm{O}-2,4$ linked L-rhamnose. Another two 
signals at approximately 1.12 and $1.18 \mathrm{ppm}$ were designated for the acetyl groups binding at 2and 3-O-galacturonic acid (GalA), respectively [50]. The powerful peaks at around $3.68 \mathrm{ppm}$ derived from methoxyl groups attached to carboxyl (R-COOH) groups of esterified GalA residues [50]. These groups are also correlated with the $\mathrm{COO}$ group of phenolic compounds $(\delta$ 176.4) as shown in ${ }^{13} \mathrm{C}$ NMR spectra (Figure 5B) [51]. The second region containing five intensive peaks of both spectra were allocated the esterified GalA, including H-1 4.95, H-2 3.64, H-3 3.86, H-4 4.05, and H-5 4.95 ppm, proposing that GalA was the major constituent [52]. The chemical shift of $\mathrm{H}-1$ observed at the region around $4.95 \mathrm{ppm}$ is characteristic of the $\alpha$-glycoside linkage of GalA, whereas an anomeric region with signals at approximately 5.09 and $5.17 \mathrm{ppm}$ was designated to the $\mathrm{H}-1$ of Ara and Rha, respectively [50].

${ }^{1} \mathrm{H}_{-}{ }^{13} \mathrm{C}$ hetero-correlated HSQC spectra of the purified conjugates (Figure $5 \mathrm{C}$ and $5 \mathrm{D}$ ) provided more information on cross-peak signal assignments based on the literature data. The cross-peak located at 1.24/17.2 in the HSQC NMR spectra due to the rhamnose (Rha) component in the conjugates. Besides, the signals were at approximately $4.55 / 103.5$ and $4.65 / 105.5$ due to $\beta$ galactose (terminal $\beta \mathrm{Gal}$ ) and internal 1,4-linked $\beta \mathrm{Gal}$ and/or internal 1,3-linked $\beta \mathrm{Gal}$. Another cross-peak was observed at around 5.16/107.3, which is characteristic of $\alpha$ Araf demonstrating its origin in $1,2,5-$ or $1,3,5$-linked $\alpha$ Araf, primarily due to its branching by $\beta \mathrm{Gal}$ and/or its oligosaccharides [41].

\subsection{Gel permeation chromatography (GPC)}

The molecular mass of the PP-PLE5 was distributed in a wide range from Mp 0.18 to $>642 \mathrm{kDa}$ (Figure 6). There were three peaks with a dominance of low molecular peak at approximately 8 $\mathrm{kDa}$, which could have resulted from the hydrothermal degradation of PP under subcritical water conditions. The second peak was observed at $21.5 \mathrm{~min}$, with a molecular weight of about 83.5 
$\mathrm{kDa}$. The third low-intensity peak observed at 19 min was characteristic of high molecular mass with $>642 \mathrm{kDa}$. Under the subcritical water state, the carbohydrates were converted into monosaccharides, which are mainly glucose [45], resulting in a decrease in molecular weight. PP-PLE5 was rich in carbohydrate content $(26.58 \%$, w/w) and phenolic content ( $265 \mathrm{mg}$ GAE $\mathrm{g}^{-1}$ ) but low in protein content $(1.48 \%, \mathrm{w} / \mathrm{w})$. Galactose, glucose, and rhamnose were the main neutral sugars comprised of carbohydrates part with $22.87 \%, 20.16 \%$, and $29.22 \%$, respectively.

\section{Conclusion}

PP conjugates were successfully isolated from $P$. palatiferum using both conventional and green techniques. The biological activity and chemical profiles depended on the extraction conditions. PP-PLE conjugates obtained at $200{ }^{\circ} \mathrm{C}$ possessed the most carbohydrate; however, due to the thermal degradation of PP, they had the lowest anticoagulant activity. On the other hand, the anticoagulant effects of PP conjugates achieved from PLE at $150{ }^{\circ} \mathrm{C}$ were comparable to those of the conventional technique. In this study, we found that subcritical water is more appropriate to recover PP as compared with $60 \%$ aqueous ethanol under the same conditions. The results of this study revealed that PLE can be a potential candidate for the recovery of PP conjugates from medicinal plants. A new procedure for the isolation and purification of PP conjugates using this green effective technique was also proposed.

Declarations of interest: none

\section{Acknowledgments}

This research was supported by Basic Science Research Program through the National Research Foundation of Korea (NRF) funded by the Ministry of Education (NRF-2019R1I1A3A01062514). 


\section{References}

[1] M. Tsirigotis-Maniecka, I. Pawlaczyk-Graja, R. Ziewiecki, S. Balicki, M. Matulová, P. Capek, F.

Czechowski, R. Gancarz, The polyphenolic-polysaccharide complex of Agrimonia eupatoria L. as an indirect thrombin inhibitor - isolation and chemical characterization, International Journal of Biological Macromolecules, 125 (2019) 124-132.

[2] I. Pawlaczyk-Graja, S. Balicki, R. Ziewiecki, M. Matulová, P. Capek, R. Gancarz, Polyphenolicpolysaccharide conjugates of Sanguisorba officinalis L. with anticoagulant activity mediated mainly by heparin cofactor II, International journal of biological macromolecules, 93 (2016) 1019-1029.

[3] I. Pawlaczyk-Graja, Polyphenolic-polysaccharide conjugates from flowers and fruits of single-seeded hawthorn (Crataegus monogyna Jacq.): Chemical profiles and mechanisms of anticoagulant activity, International Journal of Biological Macromolecules, 116 (2018) 869-879.

[4] I. Pawlaczyk, L. Czerchawski, W. Kuliczkowski, B. Karolko, W. Pilecki, W. Witkiewicz, R. Gancarz, Anticoagulant and anti-platelet activity of polyphenolic-polysaccharide preparation isolated from the medicinal plant Erigeron canadensis L, Thrombosis Research, 127 (2011) 328-340.

[5] I. Pawlaczyk, P. Capek, L. Czerchawski, J. Bijak, M. Lewik-Tsirigotis, A. Pliszczak-Król, R. Gancarz, An anticoagulant effect and chemical characterization of Lythrum salicaria L. glycoconjugates, Carbohydrate Polymers, 86 (2011) 277-284.

[6] S. Pirestani, A. Nasirpour, J. Keramat, S. Desobry, Preparation of chemically modified canola protein isolate with gum Arabic by means of Maillard reaction under wet-heating conditions, Carbohydrate polymers, 155 (2017) 201-207.

[7] R.M. Adam G. Carr, N.R. Foster, A review of subcritical water as a solvent and its utilization for the processing of hydrophobic organic compounds, Chemical Engineering Journal, 172 (2011) 1-17.

[8] A. Mustafa, C. Turner, Pressurized liquid extraction as a green approach in food and herbal plants extraction: A review, Analytica Chimica Acta, 703 (2011) 8-18. 
[9] M. Cvjetko Bubalo, S. Vidović, I. Radojčić Redovniković, S. Jokić, New perspective in extraction of plant biologically active compounds by green solvents, Food and Bioproducts Processing, 109 (2018) 5273.

[10] I.S.M.Z. J. Azmir, M.M. Rahman, K.M. Sharif, A. Mohamed, F. Sahena, M.H.A. Jahurul, N.A.N.N. K. Ghafoor, A.K.M. Omar, Techniques for extraction of bioactive compounds from plant materials: A review, Food Engineering, 117 (2013) 426-436.

[11] L. Ramos, E. Kristenson, U.T. Brinkman, Current use of pressurized liquid extraction and subcritical water extraction in environmental analysis, Journal of Chromatography A, 975 (2002) 3-29.

[12] Q.F. Xiaoxia Liang, Application of sub-critical water extraction in pharmaceutical industry, Materials Science and Chemical Engineering, 1 (2013) 1-6.

[13] J. Liu, R. Bai, Y. Liu, X. Zhang, J. Kan, C. Jin, Isolation, structural characterization and bioactivities of naturally occurring polysaccharide-polyphenolic conjugates from medicinal plants-A review, International Journal of Biological Macromolecules, 107 (2018) 2242-2250.

[14] M. Plaza, C. Turner, Pressurized hot water extraction of bioactives, TrAC Trends in Analytical Chemistry, 71 (2015) 39-54.

[15] A. Shitu, S. Izhar, T. Tahir, Sub-critical water as a green solvent for production of valuable materials from agricultural waste biomass: a review of recent work, Global Journal of Environmental Science and Management, 1 (2015) 255-264.

[16] A.G. Carr, R. Mammucari, N.R. Foster, A review of subcritical water as a solvent and its utilization for the processing of hydrophobic organic compounds, Chemical Engineering Journal, 172 (2011) 1-17. [17] T.C. Ho, B.S. Chun, Extraction of bioactive compounds from Pseuderanthemum palatiferum (Nees) Radlk. using subcritical water and conventional solvents: A comparison study, Journal of food science, 84 (2019) 1201-1207.

[18] Ö. Seçmeler, Ö. Güçlü Üstündağ, J. Fernández-Bolaños, G. Rodríguez-Gutiérrez, Effect of subcritical water and steam explosion pretreatments on the recovery of sterols, phenols and oil from olive pomace, Food Chemistry, 265 (2018) 298-307. 
[19] L.T.P. Trinh, Y.-S. Choi, H.-J. Bae, Production of phenolic compounds and biosugars from flower resources via several extraction processes, Industrial Crops and Products, 125 (2018) 261-268.

[20] S.-Y.Y. Chan-Ick Cheigh, Min-Jung Ko, Pahn-Shick Chang, Myong-Soo Chung, Extraction characteristics of subcritical water depending on the number of hydroxyl group in flavonols, Food Chemistry, 168 (2015) 21-26.

[21] D.T.V. Pereira, A.G. Tarone, C.B.B. Cazarin, G.F. Barbero, J. Martínez, Pressurized liquid extraction of bioactive compounds from grape marc, Journal of Food Engineering, 240 (2019) 105-113.

[22] G.O. Corazza, D. Bilibio, O. Zanella, A.L. Nunes, J.P. Bender, N. Carniel, P.P. dos Santos, W.L. Priamo, Pressurized liquid extraction of polyphenols from Goldenberry: Influence on antioxidant activity and chemical composition, Food and Bioproducts Processing, 112 (2018) 63-68.

[23] C. He, H. Du, C. Tan, Z. Chen, Z. Chen, F. Yin, Y. Xu, X. Liu, Semi-continuous pressurized hot water extraction of black tea, Journal of Food Engineering, 227 (2018) 30-41.

[24] H.V.B. Phan Minh Giang, Phan Tong Son, Phytochemical study on Pseuderanthemum palatiferum (Nees) Radlk., Acanthaceae, Journal of Chemistry, 41(2) (2003) 115-118.

[25] P. Komonrit, R. Banjerdpongchai, Effect of Pseuderanthemum palatiferum (Nees) Radlk fresh leaf ethanolic extract on human breast cancer MDA-MB-231 regulated cell death, Tumor Biology, 40 (2018) 1010428318800182.

[26] R.T. K. Chayarop, P. Peungvicha, Y. Wongkrajang, W. Chuakul, S. Amnuoypol, N. Ruangwises, Antidiabetic effects and in vitro antioxidant activity of Pseuderanthemum (Nees) Radlk. leaf aqueous extract, Mahidol University Journal of Pharmaceutical Science, 38(3-4) (2011) 13-22.

[27] P. Padee, S. Nualkaew, C. Talubmook, S. Sakuljaitrong, Hypoglycemic effect of a leaf extract of Pseuderanthemum palatiferum (Nees) Radlk. in normal and streptozotocin-induced diabetic rats, Journal of Ethnopharmacology, 132 (2010) 491-496.

[28] A.P. Parirat Khonsung, N. Chiranthanut, S. Intahphuak, Hypotensive effect of the water extract of the leaves of Pserderanthemum palatiferum, Journal of Nature Medicine - Springer, 65 (2011) 551-558. 
[29] A.J. Pawitra Pulbutr, Bejamart Cushnie, Sakulrat Rattanakiat, Somsak Nualkaew, Anti-lipolytic, alpha-amylase inhibitory and antioxidant activities of Pseuderanthemum palatiferum (Nees) Radlk. leaf ethanolic extract, Medicinal Plant Research, 8(28) (2014) 967-974.

[30] S.C. Taddaow Khumpook, Supap Saenphet, Doungporn Amornlerdpison, Kanokporn Saenphet, Anti-inflammatory activity of ethanol extract from the leaves of Pseuderanthemum palatiferum (Nees) Radlk., Chiang Mai J. Sci, 40 (3) (2013) 321-331.

[31] S.S. Wararut Buncharoen, Kanokporn Saenphet, Acetylcholinesterase inhibitory effect of Pseuderanthemum palatiferum in Albino Rats, Trends Research in Science and Technology, 2(1) (2010) 13-18.

[32] J.-B.E. Quang Vinh Nguyen, Antimicrobial activity of some Vietnamese medical plants extracts, Medicinal Plant Research, 7(35) (2013) 2597-2605.

[33] P.S. Chow, S.M. Landhäusser, A method for routine measurements of total sugar and starch content in woody plant tissues, Tree physiology, 24 (2004) 1129-1136.

[34] A. Meda, C.E. Lamien, M. Romito, J. Millogo, O.G. Nacoulma, Determination of the total phenolic, flavonoid and proline contents in Burkina Fasan honey, as well as their radical scavenging activity, Food chemistry, 91 (2005) 571-577.

[35] R.D. M. S. Yogendra Kumar, Dipti Prasad, Kshipra Misra, Subcritical water extraction of antioxidant compounds from Seabuckthorn (Hippophae rhamnoides) leaves for the comparative evaluation of antioxidant activity, Food Chemistry, 127 (2011) 1309-1316.

[36] C.M. Pomory, Color development time of the Lowry protein assay, Analytical Biochemistry, 378 (2008) 216-217.

[37] M. Cesaretti, E. Luppi, F. Maccari, N. Volpi, A 96-well assay for uronic acid carbazole reaction, Carbohydrate Polymers, 54 (2003) 59-61.

[38] J. Kolodziejczyk-Czepas, M. Bijak, J. Saluk, M.B. Ponczek, H.M. Zbikowska, P. Nowak, M. Tsirigotis-Maniecka, I. Pawlaczyk, Radical scavenging and antioxidant effects of Matricaria chamomilla 
polyphenolic-polysaccharide conjugates, International Journal of Biological Macromolecules, 72 (2015) 1152-1158.

[39] S. Li, N.P. Shah, Characterization, antioxidative and bifidogenic effects of polysaccharides from Pleurotus eryngii after heat treatments, Food chemistry, 197 (2016) 240-249.

[40] I. Pawlaczyk, L. Czerchawski, W. Pilecki, E. Lamer-Zarawska, R. Gancarz, Polyphenolicpolysaccharide compounds from selected medicinal plants of Asteraceae and Rosaceae families: Chemical characterization and blood anticoagulant activity, Carbohydrate Polymers, 77 (2009) 568-575.

[41] I. Pawlaczyk, M. Lewik-Tsirigotis, P. Capek, M. Matulová, V. Sasinková, P. Dąbrowski, W. Witkiewicz, R. Gancarz, Effects of extraction condition on structural features and anticoagulant activity of F. vesca L. conjugates, Carbohydrate Polymers, 92 (2013) 741-750.

[42] I. Pawlaczyk, A. Drożdżyńska, P. Capek, M. Lewik-Tsirigotis, R. Ziewiecki, R. Gancarz, Anticoagulant activity of the polysaccharide-polyphenolic conjugate from S. officinalis L, in Proceedings of the 8th International Conference on Polysaccharides-Glycoscience, 2012, pp. 23-27.

[43] M. Uematsu, E. Frank, Static dielectric constant of water and steam, Journal of Physical and Chemical Reference Data, 9 (1980) 1291-1306.

[44] E. ToolBox, Dielectric Constant of Liquids, (2008).

[45] S.S. Toor, L. Rosendahl, A. Rudolf, Hydrothermal liquefaction of biomass: A review of subcritical water technologies, Energy, 36 (2011) 2328-2342.

[46] J. Wiboonsirikul, S. Adachi, Extraction of functional substances from agricultural products or byproducts by subcritical water treatment, Food science and technology research, 14 (2008) 319-319.

[47] S. Hata, J. Wiboonsirikul, A. Maeda, Y. Kimura, S. Adachi, Extraction of defatted rice bran by subcritical water treatment, Biochemical Engineering Journal, 40 (2008) 44-53.

[48] M. Kacurakova, P. Capek, V. Sasinkova, N. Wellner, A. Ebringerova, FT-IR study of plant cell wall model compounds: pectic polysaccharides and hemicelluloses, Carbohydrate polymers, 43 (2000) 195203. 
[49] A.T. Getachew, H.J. Lee, Y.J. Cho, S.J. Chae, B.S. Chun, Optimization of polysaccharides extraction from Pacific oyster (Crassostrea Gigas) using subcritical water: Structural characterization and biological activities, International journal of biological macromolecules, 121 (2019) 852-861.

[50] V.M. Sava, S.-M. Yang, M.-Y. Hong, P.-C. Yang, G.S. Huang, Isolation and characterization of melanic pigments derived from tea and tea polyphenols, Food Chemistry, 73 (2001) 177-184.

[51] X. Zhu, X. Dong, Y. Wang, P. Ju, S. Luo, Phenolic Compounds from Viburnum cylindricum, Helvetica Chimica Acta, 88 (2005) 339-342.

[52] R.D. Rosenberg, Biochemistry of heparin antithrombin interactions, and the physiologic role of this natural anticoagulant mechanism, The American Journal of Medicine, 87 (1989) S2-S9. 
Figures

1 - Solvent reservoir

2 - HPLC pump

3,6 - Valves

4 - Thermostatic bath

5 - Reactor

7 - Heat exchanger

8 - Controller

9 - Back pressure regulator

10 - Collection vessel

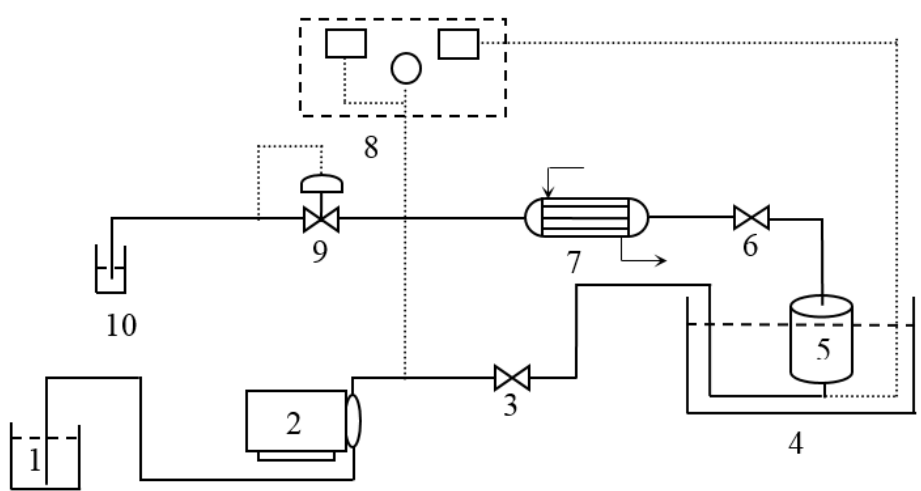

Figure 1. Diagram of the pressurized liquid extraction system 


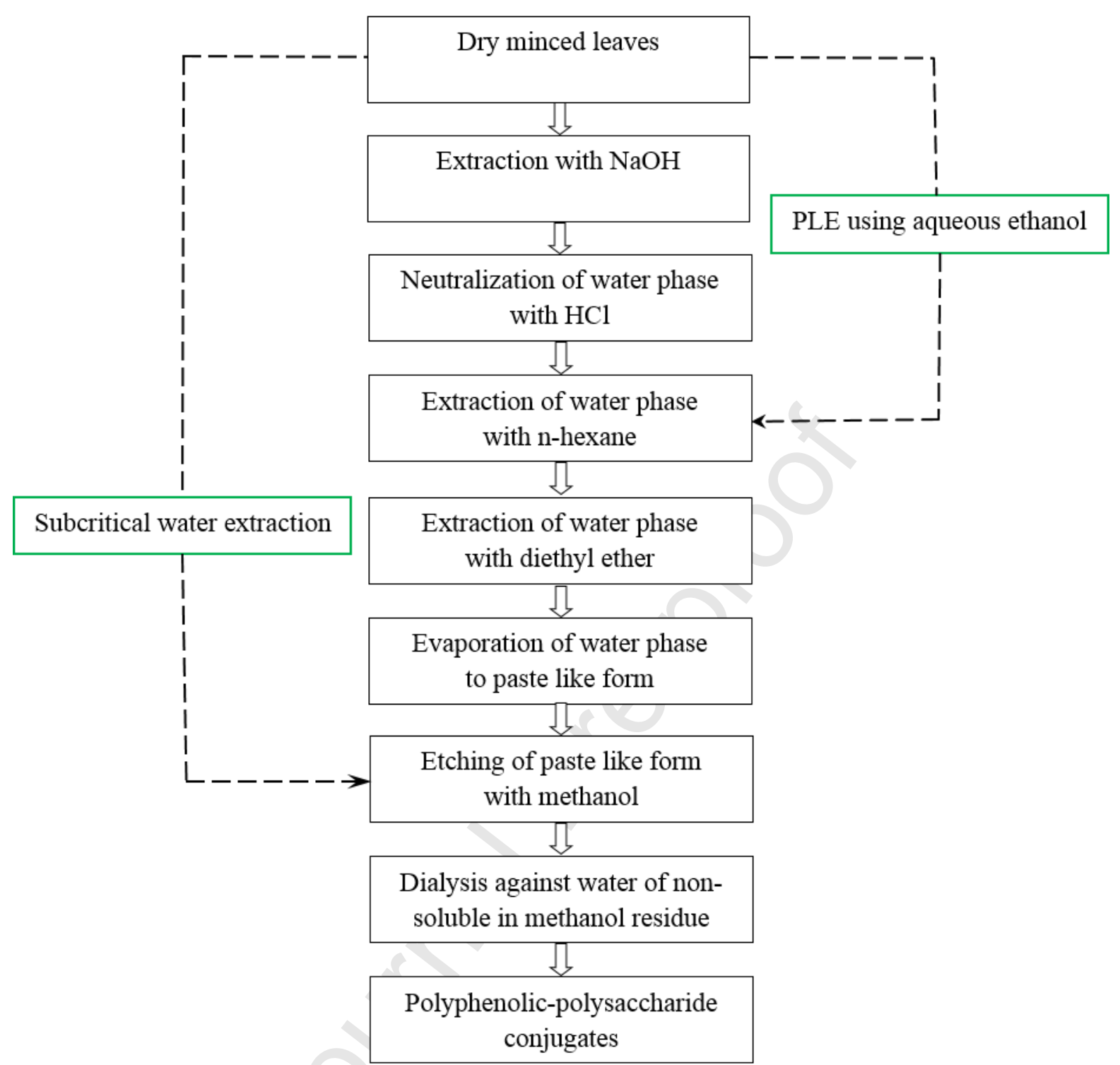

Figure 2. Isolation and purification steps of $P$. palatiferum conjugates 

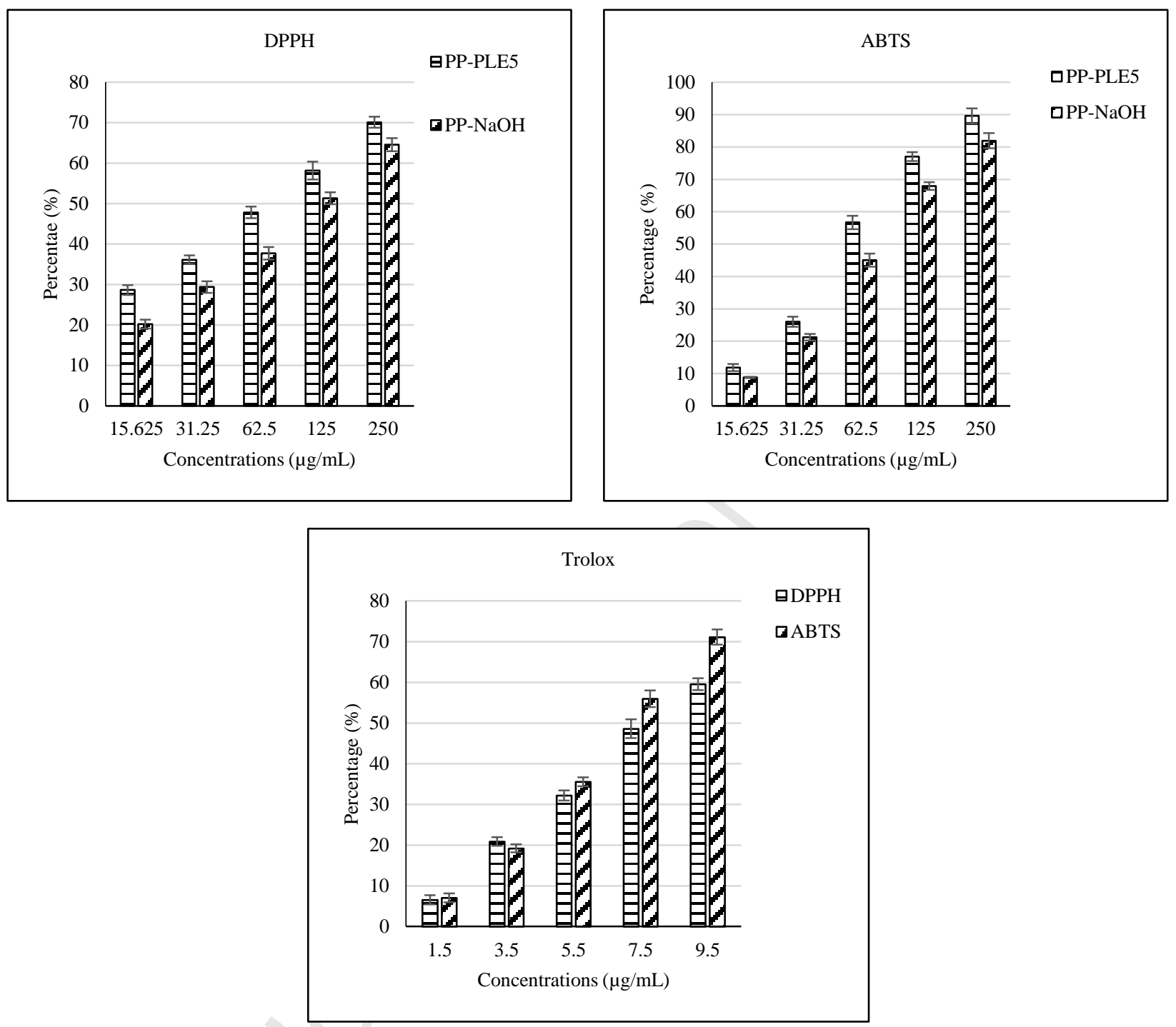

Figure 3. Antioxidant activity of PP-PLE5, PP-NaOH conjugates, and Trolox 

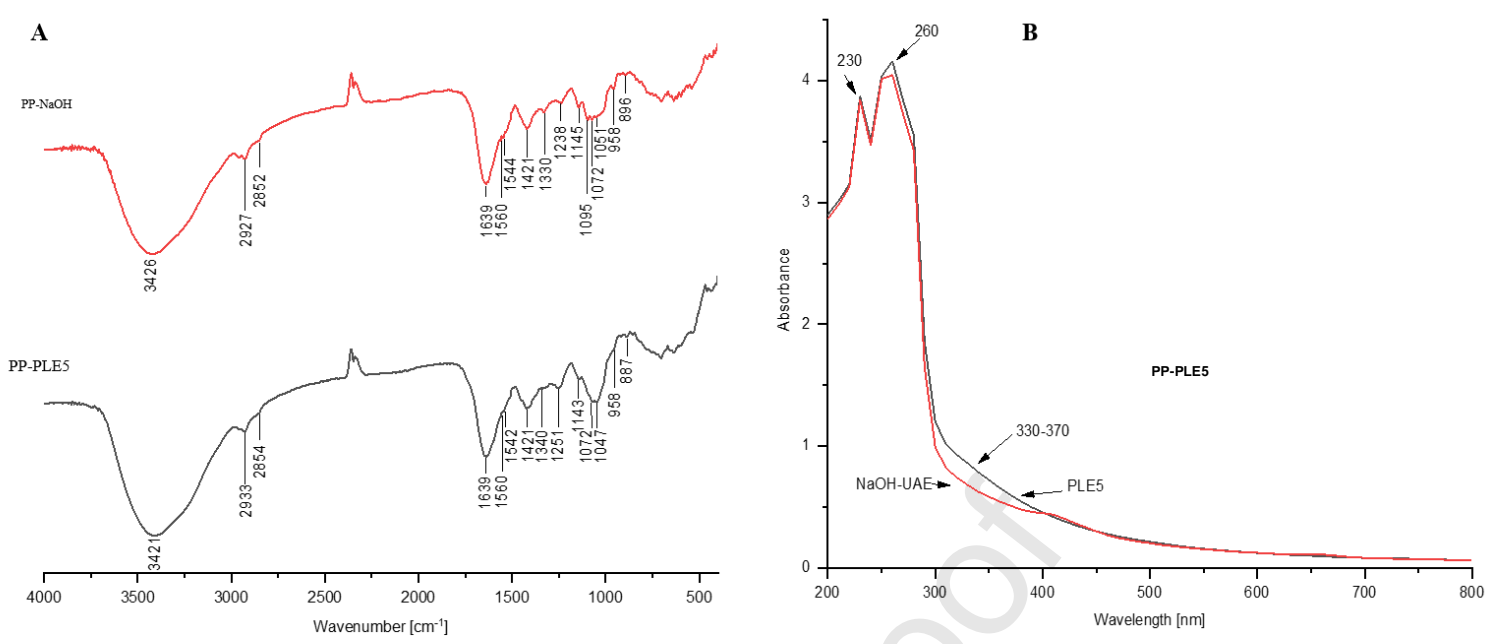

Figure 4. FT-IR (A) and UV-Vis (B) spectra of PP-PLE5 and PP-NaOH conjugates 

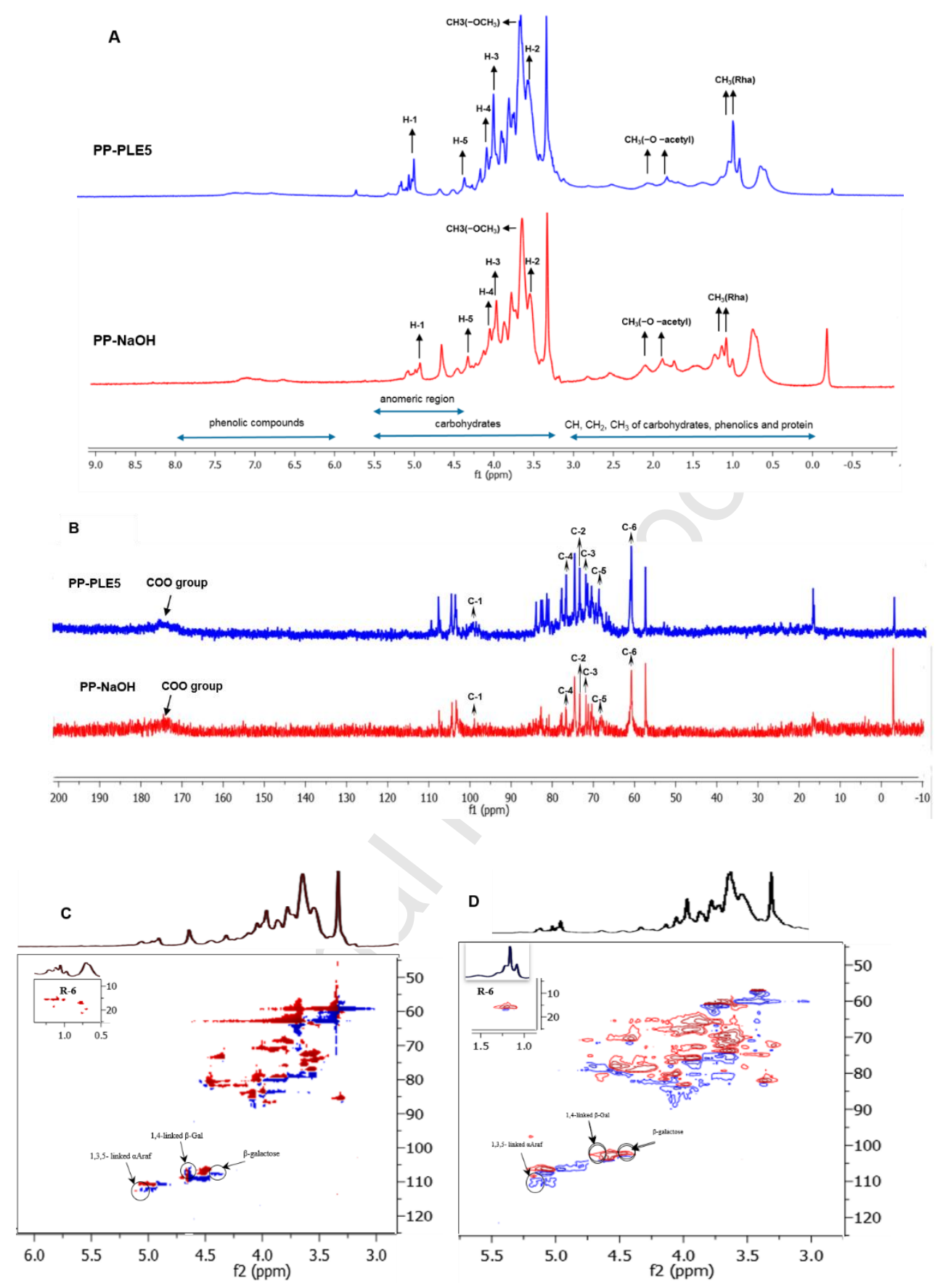

Figure 5. ${ }^{1} \mathrm{H}-\mathrm{NMR}$ and ${ }^{13} \mathrm{C}-\mathrm{NMR}$ NMR spectra of PP conjugates from $P$. palatiferum leaves: A - ${ }^{1} \mathrm{H}$ NMR of PP-

\section{PLE5}

and PP-NaOH; B - ${ }^{13} \mathrm{C}$ NMR of PP-PLE5 and PP-NaOH; C and D - HSQC NMR of PP-PLE5 and PP-NaOH, respectively. 


\section{Journal Pre-proof}

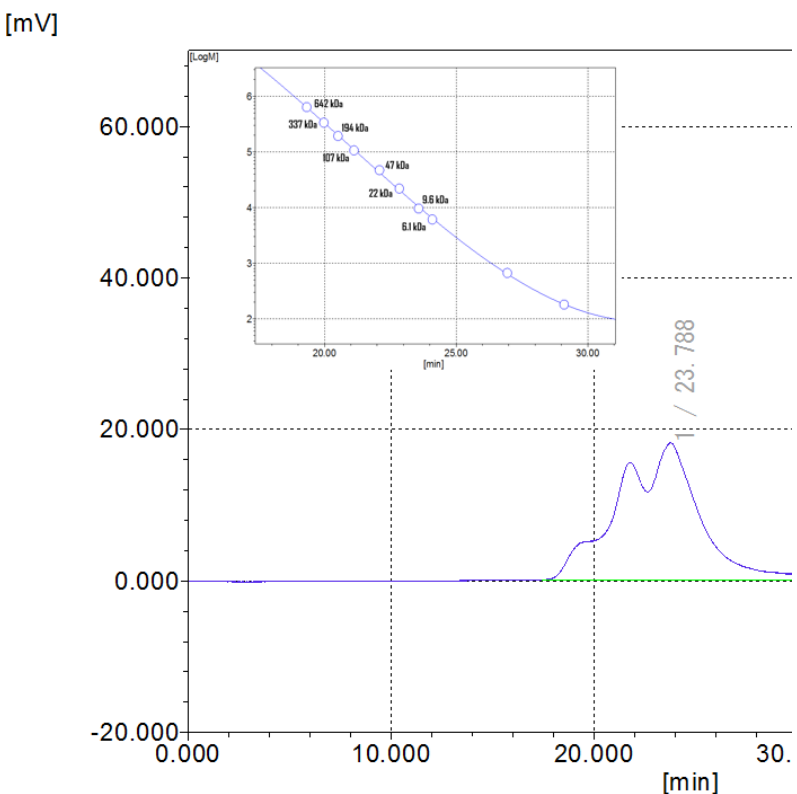

Figure 6. Gel permeation chromatography (GPC) of PP-PLE5 conjugates. Molecular weight was expressed as g/mol.

\section{Table 1}

Chemical profiles of PP conjugates isolated from $P$. palatiferum leaves

\begin{tabular}{|c|c|c|c|c|c|c|c|c|}
\hline \multicolumn{2}{|l|}{ Compositions } & PP-PLE1 & PP-PLE2 & PP-PLE3 & PP-PLE4 & PP-PLE5 & PP-PLE6 & PP- NaOH \\
\hline \multicolumn{2}{|l|}{ Yield $(w t \%)$} & 3.63 & 6.84 & 3.93 & 2.76 & 6.06 & 6.20 & 14.34 \\
\hline \multicolumn{2}{|l|}{ Carbohydrate content (wt\%) } & $31.94 \pm 2.35$ & $27.10 \pm 1.45$ & $23.77 \pm 2.29$ & $18.41 \pm 1.15$ & $26.58 \pm 0.54$ & $23.85 \pm 2.17$ & $15.58 \pm 0.58$ \\
\hline \multicolumn{2}{|l|}{ Protein content (wt\%) } & $1.72 \pm 0.50$ & $4.02 \pm 1.18$ & $1.30 \pm 1.00$ & $1.16 \pm 0.40$ & $1.48 \pm 0.48$ & $1.90 \pm 0.85$ & $2.14 \pm 1.40$ \\
\hline \multicolumn{2}{|l|}{ Uronic acid (wt\%) } & $13.43 \pm 0.43$ & $16.77 \pm 1.99$ & $19.79 \pm 1.38$ & $17.91 \pm 1.39$ & $18.14 \pm 1.04$ & $18.50 \pm 1.59$ & $20.86 \pm 1.11$ \\
\hline \multirow[t]{7}{*}{ Monosaccharides composition [wt \%] } & Ara & $9.89 \pm 0.02$ & $8.76 \pm 0.02$ & $8.45 \pm 0.06$ & $9.56 \pm 0.31$ & $10.22 \pm 1.21$ & $9.21 \pm 0.01$ & $10.27 \pm 0.02$ \\
\hline & Fuc & $1.71 \pm 0.03$ & $2.84 \pm 0.01$ & $3.1 \pm 0.09$ & $3.51 \pm 0.51$ & $3.64 \pm 0.79$ & $3.12 \pm 0.04$ & $3.26 \pm 0.03$ \\
\hline & Gal & $20.61 \pm 0.01$ & $19.23 \pm 0.01$ & $23.86 \pm 0.01$ & $23.65 \pm 0.01$ & $22.87 \pm 0.01$ & $18.62 \pm 0.01$ & $21.33 \pm 0.11$ \\
\hline & Glu & $25.92 \pm 0.01$ & $23.65 \pm 0.04$ & $20.34 \pm 0.01$ & $19.25 \pm 0.01$ & $20.16 \pm 0.01$ & $23.3 \pm 0.01$ & $22.11 \pm 0.11$ \\
\hline & Man & $7.66 \pm 0.01$ & $8.25 \pm 0.01$ & $9.21 \pm 0.01$ & $9.47 \pm 0.06$ & $8.93 \pm 0.11$ & $8.26 \pm 0.11$ & $10.24 \pm 0.13$ \\
\hline & Rha & $27.68 \pm 0.01$ & $28.21 \pm 0.01$ & $30.26 \pm 0.01$ & $29.17 \pm 0.01$ & $29.22 \pm 0.01$ & $29.11 \pm 0.01$ & $28.19 \pm 0.11$ \\
\hline & Xyl & $7.12 \pm 0.03$ & $8.25 \pm 0.1$ & $3.24 \pm 0.21$ & $4.28 \pm 0.12$ & $4.38 \pm 1.32$ & $8.74 \pm 1.12$ & $5.36 \pm 0.13$ \\
\hline \multicolumn{2}{|l|}{ Total phenolic content (mg GAE $\mathbf{g}^{-1}$ ) } & $157.32 \pm 0.49$ & $151.95 \pm 0.85$ & $172.29 \pm 0.91$ & $201.99 \pm 0.98$ & $264.66 \pm 2.54$ & $180.48 \pm 0.74$ & $216.92 \pm 1.29$ \\
\hline \multicolumn{2}{|l|}{ Total flavonoid content ( $\mathrm{mg} \mathrm{RE} \mathrm{g}^{-1}$ ) } & $75.23 \pm 1.01$ & $99.82 \pm 1.32$ & $111.97 \pm 2.33$ & $115.98 \pm 2.72$ & $135.83 \pm 1.66$ & $99.09 \pm 2.15$ & $118.03 \pm 2.37$ \\
\hline
\end{tabular}

PP-PLE1: PP extracted at $5 \mathrm{~mL} / \mathrm{min}-200{ }^{\circ} \mathrm{C}-60 \%$ ethanol

PP-PLE2: PP extracted at $5 \mathrm{~mL} / \mathrm{min}-200{ }^{\circ} \mathrm{C}$ - water 
PP-PLE3: PP extracted at $5 \mathrm{~mL} / \mathrm{min}-150{ }^{\circ} \mathrm{C}$ - water

PP-PLE4: PP extracted at $10 \mathrm{~mL} / \mathrm{min}-150{ }^{\circ} \mathrm{C}-60 \%$ ethanol

PP-PLE5: PP extracted at $10 \mathrm{~mL} / \mathrm{min}-150{ }^{\circ} \mathrm{C}$ - water

PP-PLE6: PP extracted at $10 \mathrm{~mL} / \mathrm{min}-200{ }^{\circ} \mathrm{C}-60 \%$ ethanol

PP-NaOH: PP extracted at with $0.1 \mathrm{M} \mathrm{NaOH}$

Table 2. Measurements of activated thromboplastin time (aPTT) tests of conjugates using in vitro experiments in human pooled plasma. Heparin sodium salt from porcine intestinal mucosa (180 UI $\left.\mathrm{mg}^{-1}\right)$ was used as a reference substance. Measurements are performed in triplicates and standard deviation ( \pm S.D.) was reported.

\begin{tabular}{|c|c|c|c|c|c|c|c|c|c|c|c|c|}
\hline \multirow[b]{3}{*}{$\begin{array}{c}\text { Sampl } \\
\text { e }\end{array}$} & \multicolumn{12}{|c|}{ aPTT test (s) } \\
\hline & \multicolumn{12}{|c|}{ Concentration of conjugates $(\mu \mathrm{g} / \mathrm{mL})$} \\
\hline & 4000 & 2000 & 1000 & 500 & 250 & 125 & 62.5 & 31.25 & 15.62 & 7.81 & 3.91 & $\begin{array}{c}\text { Contro } \\
1 \text { - } 0\end{array}$ \\
\hline $\begin{array}{l}\text { Hepar } \\
\text { in }\end{array}$ & - & - & - & - & - & - & & $>600$ & $>600$ & $\begin{array}{l}350 \pm \\
2.0\end{array}$ & $\begin{array}{l}270.6 \pm \\
3.1\end{array}$ & $\begin{array}{l}34.3 \pm \\
0.6\end{array}$ \\
\hline PP- & $365.1 \pm$ & $139.2 \pm$ & $105.6 \pm$ & $86.2 \pm$ & $61.3 \pm$ & $49.6 \pm$ & $39.6 \pm$ & $36.5 \pm$ & 35.1 & 35.6 & $34.2 \pm$ & $34.5 \pm$ \\
\hline PLE1 & 3.2 & 1.8 & 2.1 & 1.6 & 1.1 & 0.8 & 0.7 & 0.6 & \pm 1.0 & \pm 0.5 & 0.8 & 0.5 \\
\hline PP- & $570.3 \pm$ & $240.6 \pm$ & $140.3 \pm$ & $100.2 \pm$ & $70.2 \pm$ & $56.3 \pm$ & $44.3 \pm$ & $40.2 \pm$ & 36.6 & 35.4 & $35.2 \pm$ & $35.6 \pm$ \\
\hline PLE2 & 2.5 & 2.4 & 2.3 & 1.3 & 1.5 & 0.9 & 0.6 & 0.9 & \pm 0.7 & \pm 0.7 & 0.7 & 0.7 \\
\hline PP- & & $545.7 \pm$ & $456.1 \pm$ & 301.7 & $199.4 \pm$ & $157.4 \pm$ & $98.7 \pm$ & $71.4 \pm$ & $54.3 \pm$ & $37.6 \pm$ & $34.6 \pm$ & $35.2 \pm$ \\
\hline PLE3 & $>600$ & 2.8 & 3.6 & \pm 2.1 & 1.6 & 2.5 & 1.4 & 0.8 & 0.9 & 0.8 & 0.4 & 0.8 \\
\hline PP- & & $500.2 \pm$ & $430.4 \pm$ & $296.3 \pm$ & $196.7 \pm$ & $152.1 \pm$ & $96.2 \pm$ & $69.7 \pm$ & $52.2 \pm$ & $36.3 \pm$ & $34.8 \pm$ & $34.6 \pm$ \\
\hline PLE4 & $>600$ & 2.7 & 2.5 & 2.9 & 2.3 & 2.6 & 1.1 & 1.1 & 0.6 & 0.6 & 0.5 & 0.6 \\
\hline PP- & & & $492.7 \pm$ & $335.4 \pm$ & $226.4 \pm$ & $162.5 \pm$ & $104.5 \pm$ & $73.3 \pm$ & $54.6 \pm$ & $41.7 \pm$ & $34.3 \pm$ & $34.8 \pm$ \\
\hline PLE5 & $>600$ & $>600$ & 2.8 & 2.7 & 2.6 & 2.3 & 1.8 & 1.2 & 0.7 & 0.4 & 0.7 & 0.6 \\
\hline PP- & $451.6 \pm$ & $190.3 \pm$ & $109.7 \pm$ & $95.5 \pm$ & $68.4 \pm$ & 51.1 & $42.6 \pm$ & $37.6 \pm$ & $35.1 \pm$ & $35.5 \pm$ & $34.6 \pm$ & $35.3 \pm$ \\
\hline PLE6 & 2.8 & 2.1 & 1.8 & 1.3 & 0.8 & \pm 0.7 & 0.6 & 0.8 & 0.3 & 0.7 & & 0.4 \\
\hline PP- & & & $498.1 \pm$ & $295.2 \pm$ & $189.7 \pm$ & $136.5 \pm$ & $87.4 \pm$ & $59.4 \pm$ & $45.4 \pm$ & $35.8 \pm$ & $34.2 \pm$ & $34.6 \pm$ \\
\hline $\mathrm{NaOH}$ & $>600$ & $>600$ & 3.3 & 2.8 & 1.6 & 1.6 & 1.3 & 0.5 & 0.6 & 0.9 & 0.4 & 0.8 \\
\hline
\end{tabular}

PP-PLE1: PP extracted at $5 \mathrm{~mL} / \mathrm{min}-200{ }^{\circ} \mathrm{C}-60 \%$ ethanol

PP-PLE2: PP extracted at $5 \mathrm{~mL} / \mathrm{min}-200{ }^{\circ} \mathrm{C}$ - water

PP-PLE3: PP extracted at $5 \mathrm{~mL} / \mathrm{min}-150{ }^{\circ} \mathrm{C}-$ water

PP-PLE4: PP extracted at $10 \mathrm{~mL} / \mathrm{min}-150{ }^{\circ} \mathrm{C}-60 \%$ ethanol

PP-PLE5: PP extracted at $10 \mathrm{~mL} / \mathrm{min}-150{ }^{\circ} \mathrm{C}$ - water

PP-PLE6: PP extracted at $10 \mathrm{~mL} / \mathrm{min}-200{ }^{\circ} \mathrm{C}-60 \%$ ethanol

PP-NaOH: PP extracted at with $0.1 \mathrm{M} \mathrm{NaOH}$

Table 3. Prothrombin time (PT) assay of PP conjugates obtained from $P$. palatiferum leaves, made in vitro experiments in human pooled plasma 


\begin{tabular}{|c|c|c|c|c|c|c|c|c|c|c|c|c|}
\hline & \multicolumn{12}{|c|}{ Concentration of conjugates $(\mu \mathrm{g} / \mathrm{mL})$} \\
\hline & 4000 & 2000 & 1000 & $\mathbf{5 0 0}$ & 250 & 125 & 62.5 & 31.25 & 15.62 & 7.81 & 3.91 & $\begin{array}{c}\text { Control } \\
-0 \\
\end{array}$ \\
\hline & $64.7 \pm$ & $43.2 \pm$ & $24.3 \pm$ & $14.2 \pm$ & $13.3 \pm$ & $12.2 \pm$ & $13.6 \pm$ & $13.5 \pm$ & $13.2 \pm$ & $13.7 \pm$ & $13.3 \pm$ & $13.3 \pm$ \\
\hline PP-PLE1 & 1.6 & 1.7 & 1.5 & 1.5 & 1.6 & 1.1 & 0.8 & 0.6 & 0.6 & 0.6 & 1.1 & 0.7 \\
\hline & $77.3 \pm$ & $48.2 \pm$ & $26.5 \pm$ & $15.2 \pm$ & $13.3 \pm$ & $12.4 \pm$ & $13.3 \pm$ & $13.6 \pm$ & $13.2 \pm$ & $13.6 \pm$ & $13.5 \pm$ & $13.6 \pm$ \\
\hline PP-PLE2 & 1.8 & 1.5 & 1.6 & 1.6 & 1.5 & 1.3 & 0.9 & 0.8 & 0.6 & 0.8 & 0.5 & 0.6 \\
\hline & $134.8 \pm$ & $69.8 \pm$ & $49.2 \pm$ & $33.6 \pm$ & $24.4 \pm$ & $13.5 \pm$ & $13.7 \pm$ & $13.3 \pm$ & $13.4 \pm$ & $12.3 \pm$ & $13.3 \pm$ & $13.4 \pm$ \\
\hline PP-PLE3 & 2.2 & 1.8 & 1.7 & 1.4 & 1.6 & 0.9 & 1.0 & 1.0 & 1.0 & 0.8 & 0.7 & 0.7 \\
\hline PP-PLE4 & $\begin{array}{l}137.5 \pm \\
1.9\end{array}$ & $\begin{array}{l}68.3 \pm \\
1.9\end{array}$ & $\begin{array}{l}48.1 \pm \\
1.6\end{array}$ & $\begin{array}{l}34.3 \pm \\
1.5\end{array}$ & $\begin{array}{l}20.7 \pm \\
1.6\end{array}$ & $\begin{array}{l}13.3 \pm \\
1.1\end{array}$ & $\begin{array}{l}13.6 \pm \\
0.4\end{array}$ & $\begin{array}{l}13.6 \pm \\
0.5\end{array}$ & $\begin{array}{l}13.5 \pm \\
0.9\end{array}$ & $\begin{array}{l}13.5 \pm \\
0.7\end{array}$ & $\begin{array}{l}13.2 \pm \\
1.0\end{array}$ & $\begin{array}{l}13.3 \pm \\
0.9\end{array}$ \\
\hline PP-PLE5 & $\begin{array}{l}\mathbf{1 5 1 . 3} \pm \\
1.8\end{array}$ & $\begin{array}{l}73.5 \pm \\
1.6\end{array}$ & $\begin{array}{l}52.3 \pm \\
1.1\end{array}$ & $\begin{array}{l}35.5 \pm \\
1.4\end{array}$ & $\begin{array}{l}24.4 \pm \\
1.4\end{array}$ & $\begin{array}{l}14.6 \pm \\
1.5\end{array}$ & $\begin{array}{l}13.2 \pm \\
1.1\end{array}$ & $\begin{array}{l}13.3 \pm \\
1.0\end{array}$ & $\begin{array}{l}13.3 \pm \\
0.7\end{array}$ & $\begin{array}{l}13.3 \pm \\
0.6\end{array}$ & $\begin{array}{l}13.7 \pm \\
0.9\end{array}$ & $\begin{array}{l}13.2 \pm \\
0.9\end{array}$ \\
\hline & $67.9 \pm$ & $54.5 \pm$ & $25.2 \pm$ & $14.3 \pm$ & $13.2 \pm$ & $12.7 \pm$ & $13.3 \pm$ & $13.3 \pm$ & $13.4 \pm$ & $13.1 \pm$ & $13.8 \pm$ & $13.6 \pm$ \\
\hline PP-PLE6 & 1.2 & 1.3 & 1.8 & 1.6 & 1.3 & 1.6 & 0.8 & 0.7 & 1.0 & 1.2 & 0.8 & 0.4 \\
\hline PP-NaOH & $\begin{array}{l}152.6 \pm \\
2.1\end{array}$ & $\begin{array}{l}76.3 \pm \\
1.4\end{array}$ & $\begin{array}{l}53.6 \pm \\
1.8\end{array}$ & $\begin{array}{l}36.1 \pm \\
1.8\end{array}$ & $\begin{array}{l}25.6 \pm \\
1.7\end{array}$ & $\begin{array}{l}13.3 \pm \\
1.4\end{array}$ & $\begin{array}{l}13.2 \\
\pm 1.1\end{array}$ & $\begin{array}{l}13.7 \pm \\
0.6\end{array}$ & $\begin{array}{l}13.6 \pm \\
0.8\end{array}$ & $\begin{array}{l}13.5 \pm \\
0.7\end{array}$ & $\begin{array}{l}13.8 \pm \\
0.4\end{array}$ & $\begin{array}{l}13.4 \pm \\
0.8\end{array}$ \\
\hline
\end{tabular}

PP-PLE1: PP extracted at $5 \mathrm{~mL} / \mathrm{min}-200{ }^{\circ} \mathrm{C}-60 \%$ ethanol

PP-PLE2: PP extracted at $5 \mathrm{~mL} / \mathrm{min}-200{ }^{\circ} \mathrm{C}$ - water

PP-PLE3: PP extracted at $5 \mathrm{~mL} / \mathrm{min}-150{ }^{\circ} \mathrm{C}$ - water

PP-PLE4: PP extracted at $10 \mathrm{~mL} / \mathrm{min}-150{ }^{\circ} \mathrm{C}-60 \%$ ethanol

PP-PLE5: PP extracted at $10 \mathrm{~mL} / \mathrm{min}-150{ }^{\circ} \mathrm{C}$ - water

PP-PLE6: PP extracted at $10 \mathrm{~mL} / \mathrm{min}-200{ }^{\circ} \mathrm{C}-60 \%$ ethanol

PP-NaOH: PP extracted at with $0.1 \mathrm{M} \mathrm{NaOH}$

\section{Authorship contribution statement}

Truc Cong Ho: Conceptualization, Resources, Methodology, Investigation, Formal analysis,

Writing - Original draft preparation; Anley Teferra Kiddane: Investigation; Saravana

Periaswamy Sivagnanam: Conceptualization: Jin-Seok Park, Yeon-Jin Cho: Investigation;

Adane Tilahun Getachew: Visualization; Thanh-Tuyen Thi Nguyen: Resources; Gun-Do

Kim: Resources; Byung-Soo Chun: Resources, Supervision, Funding acquisition.

\section{Highlights}

- PP conjugates from P. palatiferum were successfully isolated using PLE and 0.1 M NaOH.

- The anticoagulant activity of PP-PLE at $150{ }^{\circ} \mathrm{C}$ was comparable to that of $0.1 \mathrm{M} \mathrm{NaOH}$.

- The obtained PP conjugates using PLE at $200{ }^{\circ} \mathrm{C}$ showed low anticoagulant activity. 
- In PLE, water recovered more PP than $60 \%$ aqueous ethanol under the same conditions. 